\title{
Development of the Indonesian and Malaysian Fire Danger Rating Systems
}

\author{
William J. de Groot • Robert D. Field • \\ Michael A. Brady • Orbita Roswintiarti • \\ Maznorizan Mohamad
}

Received: 26 May 2004 / Accepted: 18 April 2005

(C) Springer Science + Business Media B.V. 2006

\begin{abstract}
Forest and land fires in Southeast Asia have many social, economic, and environmental impacts. Tropical peatland fires affect global carbon dynamics, and haze from peat fires has serious negative impacts on the regional economy and human health. To mitigate these fire-related problems, forest and land management agencies require an early warning system to assist them in implementing fire prevention and management plans before fire problems begin. Fire Danger Rating Systems (FDRS) were developed for Indonesia and Malaysia to provide early warning of the potential for serious fire and haze events. In particular, they identify time periods when fires can readily start and spread to become uncontrolled fires and time periods when smoke from smouldering fires will cause an unacceptably high level of haze. The FDRS were developed by adapting components of the Canadian Forest Fire Danger Rating System, including the Canadian Forest Fire Weather Index (FWI) System and the Canadian Forest Fire Behavior Prediction (FBP) System, to local vegetation, climate, and fire regime conditions. A smoke potential indicator was developed using the Drought Code (DC) of the FWI System. Historical air quality analysis showed that the occurrence of severe haze events increased substantially when DC was above 400. An ignition potential indicator was developed using the Fine Fuel Moisture Code (FFMC) of the FWI System. Historical hot spot analysis, grass moisture, and grass ignition studies showed that fire occurrence and the ability for grass fires to start and spread dramatically increased when FFMC $>82$. The Initial Spread Index (ISI) of the FWI System was used to develop a difficulty of control indicator for grassland fires, a fuel type that can exhibit high rates of spread and fire intensity.
\end{abstract}

W. J. de Groot $(\triangle)$. M. A. Brady

Canadian Forest Service, 5320-122 St., Edmonton, AB Canada T6H 3S5

e-mail: bill.degroot@nrcan.gc.ca

R. D. Field

Department of Physics, University of Toronto, 60 St. George Street, Toronto, ON Canada M5S 1A7

O. Roswintiarti

Indonesian National Institute of Aeronautics and Space, Jl. Lapan No. 70, Jakarta 13710, Indonesia

M. Mohamad

Malaysian Meteorological Service, Jl. Sultan, 46667, Petaling Jaya, Malaysia 
This ISI-based indicator was developed using the grass fuel model of the FBP System, along with a standard grass fuel load and curing level estimated from previous Indonesian studies. Very high fire intensity is expected in grasslands when ISI $\geq 6$. To provide early warning, the FDRS identifies classes of increasing fire danger as the FFMC, DC, and ISI approach these key threshold values. The Indonesian FDRS is now operated nationally at the Indonesian Meteorological and Geophysical Agency. The Malaysian Meteorological Service operates the Malaysian FDRS and displays regional outputs for the Association of Southeast Asian Nations. The FDRS are being used by forestry, agriculture, environment, and fire and rescue agencies to develop and implement fire prevention, detection, and suppression plans.

Keywords Early warning · Fire behaviour · Fire danger · Fire management · Fire prevention · Fire weather · Forest and land fires · Transboundary haze

\section{Introduction}

Vegetation fire is an increasingly important issue in Southeast Asia because it has many social, economic, and environmental impacts. Indonesian and Malaysian peatlands are huge carbon stores, and there is concern that peat fires in this region could significantly contribute to global atmospheric carbon levels (Levine 1999; Page et al. 2002). Haze from smouldering peat fires has had serious negative impacts on the regional economy and human health in the past (Kunii et al. 2002; Sastry 2002). Since the last haze disaster in 1997-1998, several programs have been initiated to mitigate these fire-related problems. Detailed studies have assessed the underlying causes and impacts of fires (Applegate et al. 2001; Stolle and Lambin 2003) and their costs (Glover and Jessup 1999). Other reports address needs to strengthen institutional and management systems. The Association of Southeast Asian Nations (ASEAN) identified the need for an early warning system in the Regional Haze Action Plan to provide advanced notice of severe fire and transboundary haze episodes (Qadri 2001).

Haze events in Indonesia during 1982, 1983, 1987, 1991, 1994, 1997, 1998, and 2002 have been tightly coupled with the presence of El Niño conditions (Kita et al. 2000; Wang et al. 2004). Under El Niño conditions, reduced convective activity over Indonesia results in a pronounced rainfall deficit, which gives way to regional drought conditions during the main May-September dry season. El Niño events occur every 2-7 years, but not on a regular interannual cycle. An implication of El Niño's irregularity for fire management in Indonesia is that large-scale fire events occur episodically, and during some years are not of major concern, making resource preparedness more difficult to plan and maintain on a routine basis. As a result, real-time monitoring and forecasting of weather and fuel conditions are required to better prepare for such fire and haze events. These activities must be based on an understanding of local fire behaviour, which to date has been little studied in the tropics. While fire knowledge is extensive in temperate and northern latitudes, blanket application in the tropics will not be successful without consideration of local fuels, weather, and topography (Cochrane 2003).

This paper reports on the Southeast Asia Fire Danger Rating System Project, which was implemented in 1999 to introduce fire science in the region and to provide an early warning system of fire danger conditions that cause haze and vegetation fire problems. The system developed under this project was designed to assist countries in the region in mitigating the impacts of serious haze and uncontrolled fire by providing advanced warning to forest, land, 
and fire managers, allowing them time to implement management strategies to avert haze and fire problems before they occur.

\section{Fire danger rating}

Fire danger rating has long been used as a tool to address a wide range of fire management problems. Fire danger rating is a means of quantifying the potential or ability of a fire to start, spread, and cause damage (Merrill and Alexander 1987). Formal Fire Danger Rating Systems (FDRS) have been in development in Canada, Australia, and the United States for about 75 years (Deeming et al. 1977; Luke and McArthur 1978; Stocks et al. 1989). The Canadian Forest Fire Danger Rating System (Stocks et al. 1989) has two subsystems that are currently used operationally: the Canadian Forest Fire Weather Index (FWI) System (Van Wagner 1987) and the Canadian Forest Fire Behavior Prediction (FBP) System (Forestry Canada Fire Danger Group 1992).

The FWI System (Figure 1) provides relative indicators of general fire danger across the landscape based on weather. It comprises three fuel moisture codes representing different layers in the forest floor and three fire behaviour indices: the Fine Fuel Moisture Code (FFMC), a numerical rating of the moisture content of surface litter and other cured fine fuels on the forest floor; the Duff Moisture Code (DMC), a numerical rating of the average moisture content of loosely compacted organic layers of moderate depth in the forest floor; the Drought Code (DC), a numerical rating of the average moisture content of deep, compact organic layers in the forest floor; the Initial Spread Index (ISI), a numerical rating of the expected rate of fire spread; the Buildup Index (BUI), a numerical rating of the total amount

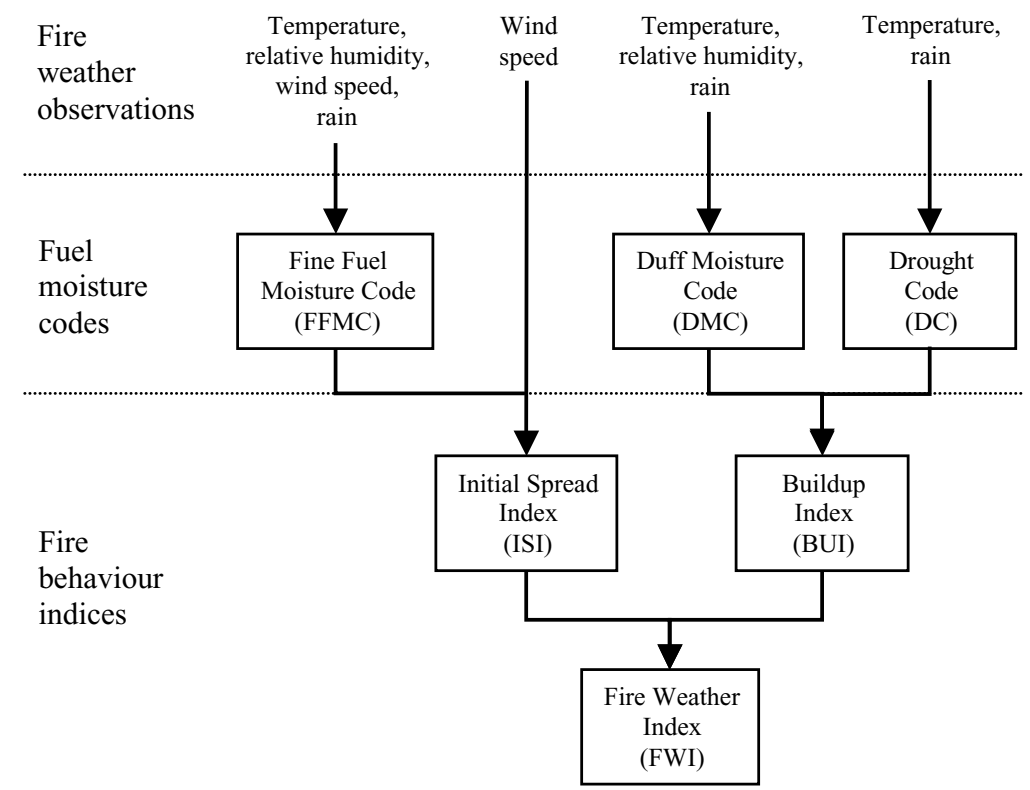

Fig. 1 Basic structure of the Canadian Forest Fire Weather Index (FWI) System (Van Wagner 1987). The FWI System has been applied in numerous other countries and regions, including Southeast Asia, to indicate general fire danger across the landscape 
of fuel available for combustion; and the Fire Weather Index (FWI), a numerical rating of fire intensity that is used as a general indicator of fire danger. The FWI System components are calculated using daily temperature, relative humidity, wind speed, and 24-hour rainfall data collected at 1200 Local Standard Time. Fire weather stations supplying these data must meet standard criteria, as described by Turner and Lawson (1978).

The FBP System provides quantitative indicators of fire danger at the stand-type level based on fuels, weather (via the FWI System), and topography. The FWI and FBP Systems have been used to estimate the probability of human-caused fire (Martell et al. 1987), potential fire activity (Forestry Canada Fire Danger Group 1992), and fire effects (de Groot et al. 2003) and are often applied in a predictive fashion to prepare in advance of serious fire problems (de Groot 1989a). They have been used to estimate fire emissions (Taylor and Armitage 1993; Amiro et al. 2001) and therefore can be readily adapted to predict smoke and haze. The FWI System has been used in various applications in numerous other countries including the United States (e.g., Brenner et al. 1997), New Zealand (National Rural Fire Authority 1993), Russia (Stocks et al. 1998), Fiji (Alexander 1989), Mexico (Lee et al. 2002), and European countries (San-Miguel-Ayanz et al. 2003). The FWI System was used as the foundation to develop the Southeast Asian FDRS that would serve as an early warning system for serious haze and fire problems.

The FDRS developed for Indonesia and Malaysia have the same structure and are based on the FWI System. However, agency-specific differences in forest and land fire management policy may result in minor differences in FDRS applications. For example, FDRS decisionaids which detail fire management actions (such as fire prevention, detection, or suppression mobilization activities) may occur at different fire danger levels in Indonesia and Malaysia because of local fire issues and fire management guidelines. The main tasks of the Southeast Asia Fire Danger Rating System Project were to conduct the initial calibration of the FWI System to regional conditions; to facilitate development of FDRS-based fire management decision-aids to address local fire problems; and to strengthen technical development, coordination, management, and integration of fire systems in the region. We report on regional calibration of the FDRS and the daily FDRS operations undertaken by Indonesia and Malaysia.

\section{Regional FDRS calibration}

A number of scientific studies were undertaken to calibrate the FDRS to the fire environment and fire problems in Southeast Asia. Components of the FWI System were directly calibrated to the equatorial region by adjusting for the number of daylight hours, or the amount of daily fuel drying time. Because there is little variation in day length at the equator, the variable monthly day length $\left(\mathrm{L}_{e}\right)$ used by Van Wagner and Pickett (1985) was adjusted to a constant value of 9.0 drying hours per day for DMC calculations and a constant day length factor $\left(\mathrm{L}_{f}\right)$ of 1.39 for DC calculations, representing the annual average value for southern and northern hemispheres.

Three components of the FWI System were further calibrated to provide advance warning of serious haze events (using DC), the potential for a large number of fire starts (using FFMC), and the potential for uncontrolled fire spread in grasslands (using ISI). Calibration of these FWI System components to local fire issues was accomplished through a combination of historical fire danger analyses and experimental field and laboratory studies.

Peat and grass fuels occur widely across Indonesia and Malaysia. Peatlands occur over large contiguous areas in both countries (Dymond et al. 2004), whereas grass occurs in small Springer 
patches scattered on the landscape. These are the most critical fuel types in both countries because of the high level of emissions coming from peatland fires causing haze (Levine 1999), the wide distribution of grass in plantations (Pickford et al. 1992) and open areas, and the high proportion of grassland area burnt (Siegert et al. 2001). Heavy fuel loads of moist tropical grasslands and frequent dry periods causing high flammability can create situations in which it is difficult to control grassland fires because of fire intensity. Therefore, calibration studies focused primarily on these two fuel types.

\subsection{Drought Code, peat fires, and haze}

As an indicator of moisture content in deep, compact organic layers, the DC has previously been calibrated to sites with deep organic soils (Lawson and Dalrymple 1996; Lawson et al. 1997). Because peat fires and haze are closely related issues, a study was undertaken to use DC as an early warning indicator of serious haze events. This was done through a historical analysis of DC and visibility. Recognizing that haze is a primary result of burning in Indonesia (Page et al. 2002), Field et al. (2004) explicitly calibrated an indicator of haze potential. This process was carried out in two steps. In the first, they developed a haze indicator to distinguish between severe haze and haze-free periods, and in the second, they associated severe haze periods with a given level of drought.

During the 1997 haze event, increasing levels of particulate matter with aerodynamic diameter $\leq 10 \mu \mathrm{m}\left(\mathrm{PM}_{10}\right)$ and total suspended particulate matter (TSP) were associated with a decrease in visibility (Heil and Goldammer 2001). Because visibility observations are taken at all synoptic meteorological stations, and hence have a greater length of record and spatial coverage than $\mathrm{PM}_{10}$ and TSP measurements, visibility was used as a haze indicator. Visibility observations are taken by visual identification of landmarks at known distances and are measured in kilometres.

Given that peat fires have been estimated to account for up to $94 \%$ of total particulate matter emissions during the 1997 haze disaster (Levine 1999), a drought indicator was selected that would reflect emissions potential from peat burning. To this end, the DC component of the FWI System was selected to indicate drought and large-emissions potential in Southeast Asian peatlands. The DC uses daily rainfall and temperature inputs, both of which are collected by Indonesia's and Malaysia's national meteorological networks. These measurements require only simple instruments, and thus they are appropriate for implementation at smaller scales, such as a district or forest management unit.

The DC has an open-ended scale, but values in North America seldom reach 800 (McAlpine 1991). High DC values indicate drier conditions in deep organic layers including peat, and the potential for deep-burning, smouldering fires increases substantially when DC exceeds about 300 (de Groot 1988). Comparing regional haze and DC over Sumatra and Kalimantan during 1994-1998, Field et al. (2004) estimated that a DC level of roughly 400 could be used as threshold for the potential of severe haze events. Although visibility can be reduced by a number of factors such as fog and industrial haze, severe haze events caused by fires are characterized by exceptionally large and often sustained decreases in visibility. Examples of the visibility and DC relationship are shown in Figure 2 for Palembang, South Sumatra, and Palangkaraya, Central Kalimantan. In 1994 and 1997, the significant decreases in visibility were well separated from typical, non-haze fluctuations at about the $8 \mathrm{~km}$ level. These low-visibility periods corresponded with substantially higher than normal DC levels. Of note is the moderate decrease in visibility seen in Palangkaraya in 1998, which apparently occurred at below-DC-threshold levels. This haze was the result of smoke transported from isolated fires in East Kalimantan, where DC levels were well above the threshold level, 
Table 1 Summary of smoke potential, Drought Code (DC) fire danger classes, and number of drying days until drought conditions are reached that can cause serious haze events

\begin{tabular}{|c|c|c|c|}
\hline $\begin{array}{l}\text { Smoke } \\
\text { potential }\end{array}$ & $\mathrm{DC}$ & $\begin{array}{l}\text { Drying days } \\
\text { before drought }\end{array}$ & Interpretation \\
\hline Low & $<140$ & $>30$ & $\begin{array}{l}\text { Typical wet-season conditions. More than } 30 \text { dry days until DC } \\
\text { reaches threshold. Severe haze periods unlikely. }\end{array}$ \\
\hline Moderate & $140-260$ & $16-30$ & $\begin{array}{l}\text { Normal mid-dry-season conditions. Between } 15 \text { and } 30 \text { dry } \\
\text { days until DC reaches threshold. Burning should be regulated } \\
\text { and monitored as usual. }\end{array}$ \\
\hline High & $260-350$ & $6-15$ & $\begin{array}{l}\text { Normal dry-season peak conditions. Between } 5 \text { and } 15 \text { dry days } \\
\text { until DC reaches threshold. All burning in peatlands should } \\
\text { be restricted. Weather forecasts and seasonal rainfall } \\
\text { assessments should be monitored closely for signs of an } \\
\text { extended dry season. }\end{array}$ \\
\hline Extreme & $>350$ & $<6$ & $\begin{array}{l}\text { Approaching disaster-level drought conditions. Fewer than } 6 \\
\text { dry days until DC reaches threshold, at which point severe } \\
\text { haze is highly likely. Complete burning restriction should be } \\
\text { enforced. }\end{array}$ \\
\hline
\end{tabular}

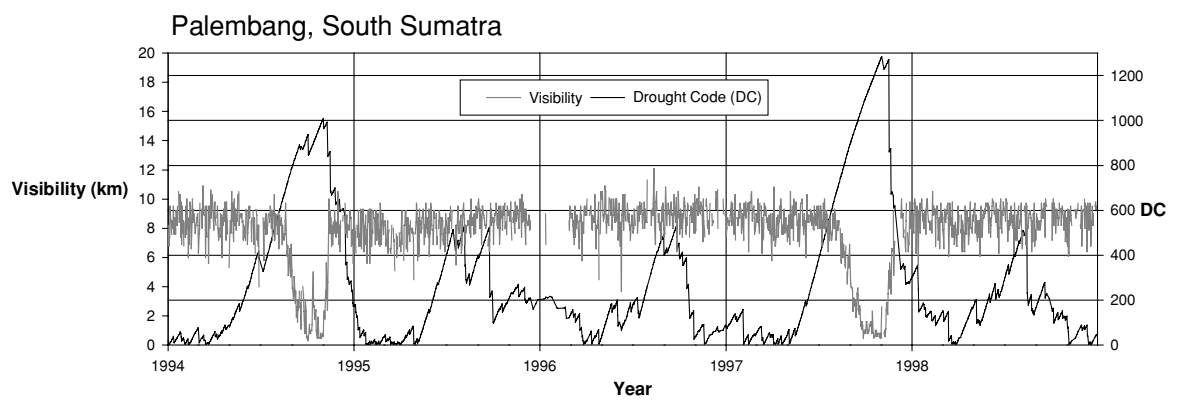

Palangkaraya, Central Kalimantan

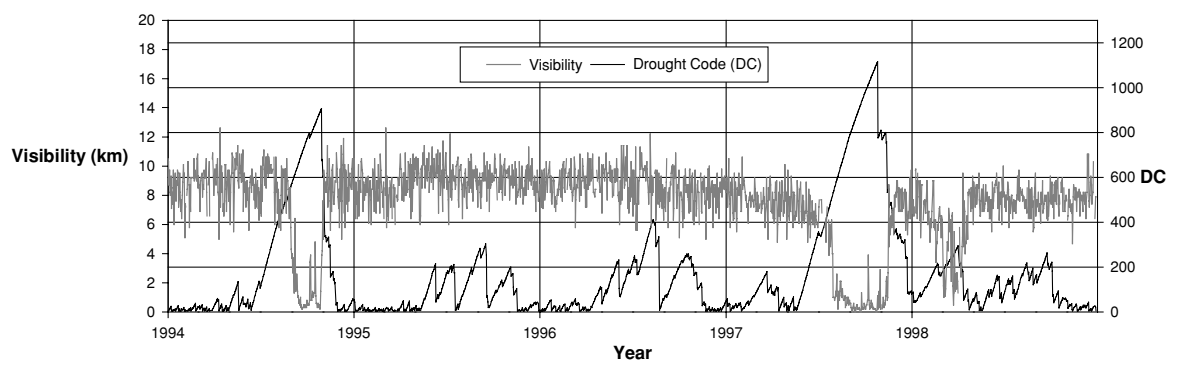

Fig. 2 Visibility and Drought Code (DC) for Palembang, South Sumatra, and Palangkaraya, Central Kalimantan, 1994-1998. Significant DC increases above 400 in 1994 and 1997 corresponded to severe haze episodes

emphasizing the importance of local fire danger monitoring. Results of this study were used to develop a fire danger classification based on smoke potential to provide early warning of serious haze events (Table 1). Specifically, the fire danger levels indicate the number of days of continuous drying until drought conditions supporting serious haze events are reached. 


\subsection{Fine Fuel Moisture Code and ignition potential}

Two separate studies were conducted to calibrate the FFMC as an ignition potential indicator in Southeast Asia. One provided a historical analysis of FFMC and hot spot occurrence, and the other conducted field and lab studies of FFMC, grass moisture, and grass ignition. Together the two studies were used to construct a fire danger classification for ignition potential in Southeast Asia based on FFMC.

\subsubsection{Fine Fuel Moisture Code and hot spots}

The FFMC is commonly used as an indicator of fire starts (Martell et al. 1987; Anderson and Englefield 2001). A study was conducted to determine the historical frequency and range of hot spot occurrence by FFMC. The study area was located between -6 to $8^{\circ}$ latitude and $89^{\circ}$ to $120^{\circ}$ longitude, which includes Sumatra and Borneo islands and peninsular Malaysia. Fire weather grids of $10 \mathrm{~km} \times 10 \mathrm{~km}$ were calculated with Spatial Fire Management System (sFMS; Lee et al. 2002) software using inverse distance weighting interpolation and 19942000 daily weather data for 32 stations (excluding 1999 data, which was unavailable). The data were acquired from the Indonesian and Malaysian Meteorological Services. Nighttime hot spot data for 1995-2000 (1999 data not included) was acquired from the World Along Track Scanning Radiometer Fire Atlas (Buongiorno et al. 1997), overlayed on the FFMC grids and assigned a numerical FFMC value.

The FFMC scale ranges from 0 to 99 with higher values indicating drier fine fuels and greater fire danger. The FFMC has a nonlinear relationship to fine fuel moisture content such that moisture content decreases at a slower rate with increasing FFMC. Values higher than 96 represent fine fuel moisture contents of about $2-4 \%$ and are seldom reached because of the extremely dry conditions necessary to maintain such low fuel moisture conditions. The highest observed FFMC value was 89 , and values greater than 85 represented less than $2 \%$ of all days (Figure 3a). The most frequent range of FFMC values was 78-85, which represented $29 \%$ of all days. There were 20,900 hot spots in the database. The data showed a general increasing trend in hot spot numbers as FFMC increased to 80 (Figure 3b), reflecting the progressive drying of fuels across the landscape. This is interpreted as being a gradual increase in the number of local dry areas occurring on the landscape as general drying progressed. As more local areas became dry enough to burn, there was a parallel increase in the number of hot spot occurrences, likely caused by increased use of prescribed fire. There was an apparent threshold near the FFMC range of 81-83, where hot spot frequency dramatically increased. Over $78 \%$ of all hot spots occurred when FFMC $>81$, even though this represented only $20 \%$ of all days. A study examining a subset of the hot spot database noted a significant increase in hot spot numbers when FFMC $>83$ (Dymond et al. 2005). The FFMC 81-83 threshold appears to indicate the point at which most open, fine fuels on the landscape have the potential to burn.

\subsubsection{Fine Fuel Moisture Code, grass moisture, and grass ignition}

Field studies were conducted in grass (mainly Imperata cylindrica) because it is usually the first fuel type to become flammable on the landscape owing to its high component of dead, fine fuels and open field conditions that allow solar radiation and surface wind to dry fuels faster than in other fuel types. Two separate studies were conducted to calibrate the FFMC to the potential for fires to start in grasslands (de Groot et al. 2005). One study calibrated FFMC to the moisture content of dead grass (the most flammable component of grasslands), 

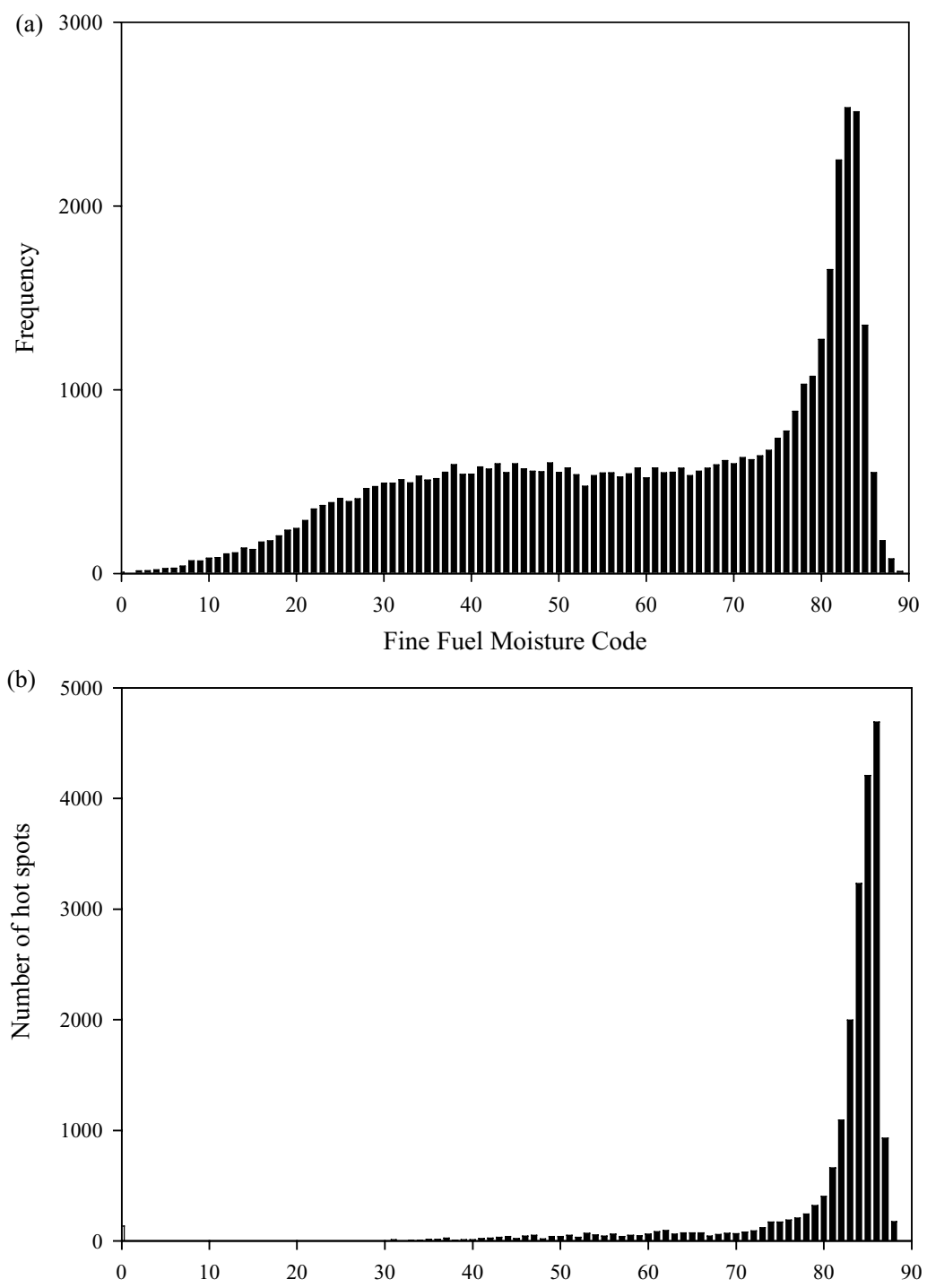

Fine Fuel Moisture Code

Fig. 3 Frequency distribution of (a) the Fine Fuel Moisture Code (FFMC) for 32 stations in Southeast Asia during 1994-2000 (1999 excluded), and (b) nighttime hot spot occurrence by FFMC for 1995-2000 (1999 excluded)

and the second study determined the threshold of grass ignition relative to moisture content, addressing major tropical fire science knowledge gaps identified by Cochrane (2003).

Three grassland sites located within $15 \mathrm{~km}$ of Pekanbaru in central Sumatra were used in the first study. Dead grass samples were collected from three clip-plots at each site every six days over an eight-month period in 2002 for moisture content determination. Daily FFMC values were calculated using local rainfall data for each site and other weather data from the Pekanbaru airport. Dead fuel moisture content and FFMC were analysed by regression. The 黛Springer 
Table 2 Summary of Fine Fuel Moisture Code (FFMC) fire danger classes and ignition potential (source: de Groot et al. 2005, used with permission)

\begin{tabular}{|c|c|c|c|c|}
\hline $\begin{array}{l}\text { Ignition } \\
\text { potential }\end{array}$ & FFMC & $\begin{array}{l}\text { Proportion of an } \\
\text { average year }^{\mathrm{a}}\end{array}$ & $\begin{array}{l}\text { Proportion of } \\
\text { fire occurrence }\end{array}$ & Interpretation \\
\hline Low & $0-72$ & 0.62 & 0.10 & Low probability of fire starts \\
\hline Moderate & $73-77$ & 0.08 & 0.04 & $\begin{array}{l}\text { Moderate probability of fire starts in areas } \\
\text { of local dryness }\end{array}$ \\
\hline High & $78-82$ & 0.16 & 0.13 & $\begin{array}{l}\text { Cured grass fuels becoming easily ignitable; } \\
\text { high probability of fire starts }\end{array}$ \\
\hline Extreme & $83+$ & 0.13 & 0.73 & $\begin{array}{l}\text { Cured grass fuels highly flammable; very } \\
\text { high probability of fire starts }\end{array}$ \\
\hline
\end{tabular}

${ }^{a}$ Based on regional fire weather data, 1994-2000 (1999 excluded)

${ }^{b}$ Based on regional hot spot data, 1995-2000 (1999 excluded)

FFMC explained 58\% of the variation in dead grass moisture content across all three sites. Grass height and total grass biomass were also highly significant factors affecting dead grass moisture content.

In the second study, the ignition threshold of dead grass was determined by conducting ignition tests at different levels of moisture content. Small samples (about $30 \mathrm{~g}$ ) of dead grass were prepared to specific moisture contents and their ignitability was determined using a simple match test (Russell and Pech 1968; Paul 1969; Lawson et al. 1994) over a range of moisture contents. The test results were analysed by logistic regression to determine the ignition threshold of dead grass. The study showed an ignition threshold $\left(P_{\text {ignition }}=0.5\right)$ near $35 \%$ moisture content in dead grass. This moisture content represented an FFMC value of 81-83 at the three grass moisture sites in the first study. The FFMC threshold value for dead grass ignition matched well with the sharp increase in hot spot numbers shown in Figure $3 b$. Therefore, the FFMC value of $82-83$ was used to identify fire danger class boundaries between high and extreme ignition potential (Table 2). The class boundary between moderate and high fire danger at FFMC 77-78 represents the lower 95\% confidence interval limit for dead grass ignition. Over $85 \%$ of all hot spots in the database occurred when FFMC $\geq 78$. The class boundary between low and moderate fire danger at FFMC 72-73 was arbitrarily set for fire management purposes to provide early warning of increasing ignition potential on the landscape.

\subsection{Initial Spread Index and difficulty of control in grasslands}

In tropical forests, most fires are of low to moderate fire intensity (Cochrane 2003) and can be directly suppressed using basic fire fighting equipment such as hand tools, power pumps, and hoses. However, it is possible for some fires to escape direct suppression action and continue to spread without control. Typically this scenario can occur in open (nonforest) fuel types with high dead fine fuel loads such as grasslands or shrublands. A fire starting in these fuel types under dry conditions and moderate winds can spread quickly through the fine fuel component. High grass fuel loads in this region (Pickford et al. 1992) and fast rates of fire spread driven by moderate winds contribute directly to high fire intensity (Byram 1959). Stott et al. (1990) have estimated fire intensity in Southeast Asian savannahs at 2000-5000 $\mathrm{kW} / \mathrm{m}$, a level much higher than can be controlled by well-equipped fire crews (Alexander and de Groot 1988). Because fire suppression capability is closely linked to fire intensity 
(Quintilio et al. 1990; Hirsch 1998), control of grassland fires can be a serious problem in Southeast Asia.

In most fuel types, the FWI is normally used as an indicator of fire intensity because it incorporates the rate of fire spread in fine fuels using the ISI input and the total amount of fuel consumed in medium and heavy fuels through the BUI input. In the case of grass, however, fire intensity can be estimated using only the ISI because there are no medium or heavy fuels in this fuel type. If the ISI, total grass fuel load, and amount cured are known, fire intensity can be calculated using the grass fuel model of the FBP System. The grass fuel model was originally developed using Australian grassland fire data.

The ISI was calibrated to be a difficulty of control indicator for grassland fires using the FBP System and standard fuel parameters for Southeast Asia. Fire danger class boundaries (low, moderate, high, extreme) were defined using thresholds of fire control based on quantitative fire intensity limits $(\mathrm{kW} / \mathrm{m})$ for different suppression resources (Table 3), similar to Alexander and de Groot (1988). Using a standard fuel load of $1.8 \mathrm{~kg} / \mathrm{m}^{2}$ (Pickford et al. 1992) and a cured level of $65 \%$, the FBP System was used to determine ISI levels that corresponded

Table 3 Summary of head fire intensity, Initial Spread Index (ISI), fire rate of spread, and average annual frequency for difficulty-of-control fire danger classes in grasslands

\begin{tabular}{|c|c|c|c|c|c|}
\hline $\begin{array}{l}\text { Difficulty } \\
\text { of control }\end{array}$ & $\begin{array}{l}\text { Estimated head } \\
\text { fire intensity } \\
\text { in grasslands } \\
(\mathrm{kW} / \mathrm{m})^{\mathrm{a}}\end{array}$ & ISI & $\begin{array}{l}\text { Fire rate } \\
\text { of spread } \\
(\mathrm{m} / \mathrm{min})\end{array}$ & $\begin{array}{l}\text { Proportion of } \\
\text { an average } \\
\text { year }^{\text {b }}\end{array}$ & Fire suppression interpretation ${ }^{\mathrm{c}}$ \\
\hline Low & $0-250$ & $0-1$ & $0-0.5$ & 0.75 & $\begin{array}{l}\text { Low fire intensity in grasslands. Fire } \\
\text { will spread slowly or be } \\
\text { self-extinguishing. Grassland fires } \\
\text { can be successfully controlled } \\
\text { using hand tools. }\end{array}$ \\
\hline Moderate & $250-1250$ & $2-3$ & $0.6-2.3$ & 0.23 & $\begin{array}{l}\text { Moderate fire intensity in grasslands. } \\
\text { Hand tools will be effective along } \\
\text { the fire's flanks, but water under } \\
\text { pressure (pumps, hose) may be } \\
\text { required to suppress the head fire } \\
\text { in grasslands. }\end{array}$ \\
\hline High & $1250-2500$ & $4-5$ & $2.4-4.6$ & 0.02 & $\begin{array}{l}\text { High fire intensity in grasslands. } \\
\text { Direct attack at the fire's head will } \\
\text { require water under pressure, and } \\
\text { mechanized equipment may be } \\
\text { required to build control lines (e.g., } \\
\text { bulldozer). }\end{array}$ \\
\hline Extreme & $2500+$ & $6+$ & $4.7+$ & $<0.01$ & $\begin{array}{l}\text { Very high fire intensity in grasslands. } \\
\text { Fire control will require } \\
\text { construction of control lines by } \\
\text { mechanized equipment and water } \\
\text { under pressure. Indirect attack by } \\
\text { back-burning between control lines } \\
\text { and the fire may be required. }\end{array}$ \\
\hline
\end{tabular}

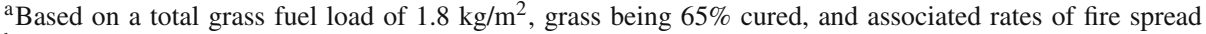

${ }^{\mathrm{b}}$ Based on regional fire weather data, 1994-2000 (excluding 1999)

${ }^{\mathrm{c}}$ Fire control limits are interpreted from head fire intensity and suppression capabilities described by Alexander and de Groot (1988) 
to the fire intensity limits of Table 3 . Although $65 \%$ cured is slightly higher than reported by Pickford et al. (1992), it is representative of the higher rates found in the grass moisture study at drier times during the year. In North America, ISI values $\geq 10$ are considered high, but these high levels rarely occur in Southeast Asia. However, even moderate ISI values of 4-5 can result in high intensity grassland fires.

\section{Daily FDRS operations}

These calibrated FDRS components are now calculated operationally by local agencies in the region. The Meteorological and Geophysical Agency Head Quarters (BMG HQ) office in Jakarta runs the Indonesia FDRS. Real-time (1200 Local Standard Time) weather data for Indonesia are collected through the synoptic (surface) station network and through the meteorological data exchange of the World Weather Watch program framework of the World Meteorological Organization. Data obtained from 163 synoptic stations are sent to five BMG subregional offices located at Medan (Sumatra), Ciputat (Java), Denpasar (Bali), Makassar (Sulawesi), and Jayapura (Irian Jaya). These offices send the data to the BMG HQ office via Very Small Aperture Terminal or lease lines of telex, fax, or telephone. At the BMG HQ office, all data are decoded and used as input to sFMS to produce daily FDRS maps of FFMC, DC, and ISI.

These outputs are displayed daily on the BMG website (Figure 4a), accessible to user agencies and the general public. As an example, the Ministry of Forestry office uses the FDRS information in several fire-prone provinces and districts in Indonesia to provide early warning information and interpretations for each area, and to prepare fire prevention guidelines based on the information. This information dissemination is supplemented by FDRS training at local levels to ensure appropriate application by operational personnel.

The Malaysia FDRS is operationally run by the Malaysian Meteorological Service (MMS) in Kuala Lumpur. Daily surface observation data from the 36 principal meteorological stations are entered into the Data Entry Communication System at each station. These national observation data are then transmitted through dial-up Internet connections or by digital leased lines into the Computer Message Switching System (CMSS). All the data required by the FDRS are received by the CMSS, decoded, and used as input to sFMS. The FDRS maps are published on the MMS website (www.kjc.gov.my) and, similarly to Indonesia, are provided to users such as the Department of Environment, the National Security Council, the Fire and Rescue Department, the Forestry Department, and agriculture agencies.

The MMS also provides regional fire danger maps for ASEAN (Figure 4b). This system currently is a prototype for general information and will be further calibrated in the future. The CMSS (in Kuala Lumpur) obtains daily surface observation data from 250 to 300 principal meteorological stations in ASEAN countries from the Global Telecommunications System. All the data are similarly processed by MMS to provide regional FDRS maps for ASEAN's Haze Online website (www.haze-online.or.id) to provide early warning of fire danger for forest and land fire management agencies in ASEAN member countries. Haze Online team members were also trained to provide daily interpretations of the FDRS maps.

Sustained use of newly transferred technology is often a challenge. To ensure ongoing FDRS operations after the Southeast Asia Fire Danger Rating System Project, a summary of FDRS technical information, reference material, guides for interpretation, and practical applications for user groups were compiled in a manual (de Groot and Field 2004). As well, FDRS operating agencies in Indonesia and Malaysia are preparing manuals of standard operating procedures. Also, a regional team of training specialists prepared a train-the-trainer 
(a) KEMUDAHAN PENYULUTAN API MENJADI KEBAKARAN PADA BAHAN BAKARAN HALUS

INDONESIA, 14 APRIL 2004

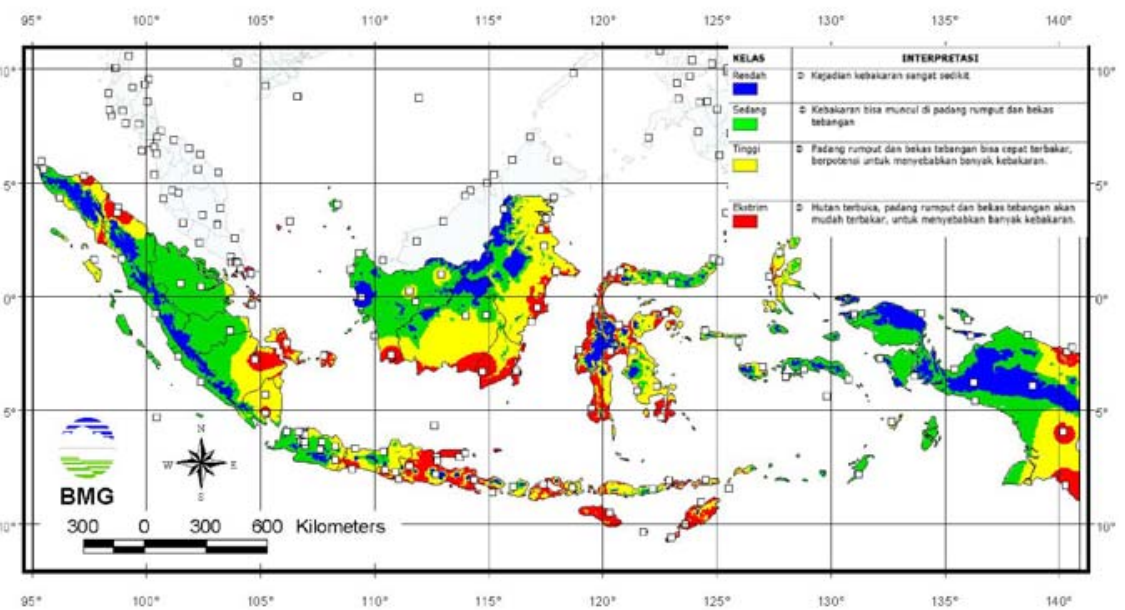

DIBUAT : 14 APRIL 2004; 16:00:00 WIBB SAMPAI: 15 APRIL $2004 ; 1600$ 00 WIBB

LAYOUT DESIGN BY BMG_GIS WORK GROUP

(b)

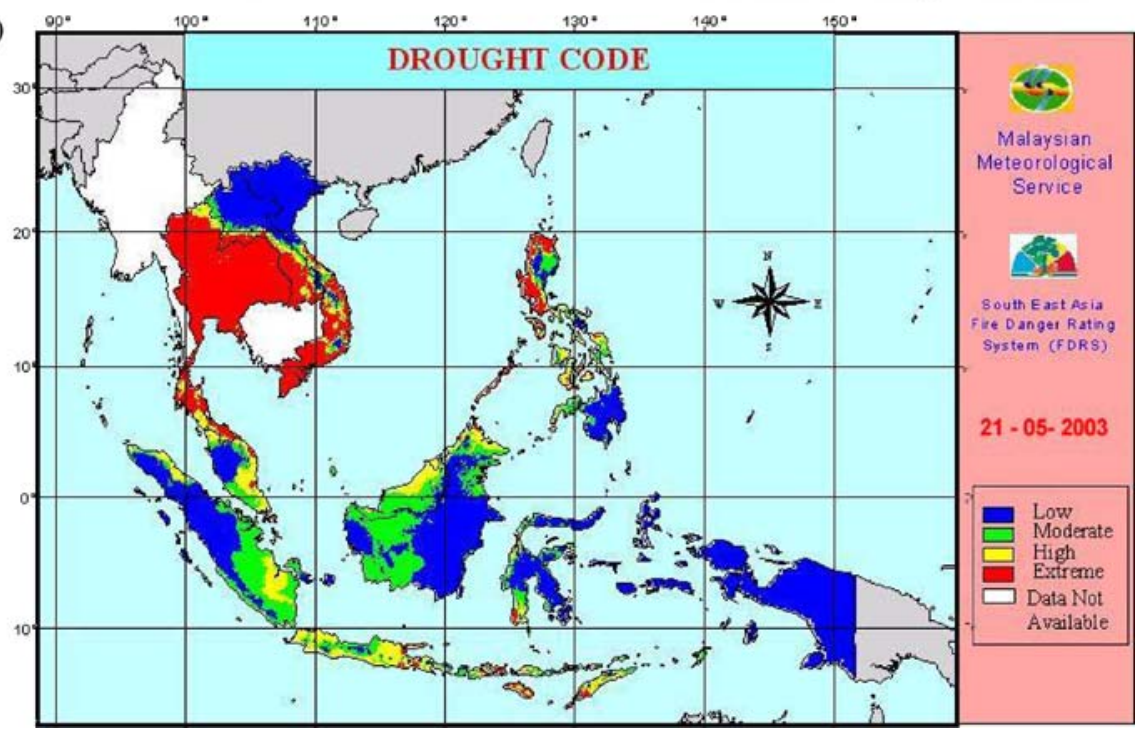

Fig. 4 Examples of daily FDRS maps showing (a) Fine Fuel Moisture Code, an indicator of ignition potential, across Indonesia, and (b) Drought Code, an indicator of smoke and haze potential, across the Southeast Asia region. Maps produced by Indonesia Meteorological and Geophysical Agency (www.bmg.go.id) and Malaysian Meteorological Service (www.kjc.gov.my and www.haze-online.or.id)

course curriculum. To date, 20 fire management specialists from Indonesia, Malaysia, and Brunei have completed the one-week course to become agency trainers. Finally, a Southeast Asia Fire Science Network was formed in 2001 to continue development of fire science expertise within the region. The network includes scientists from local universities and management agencies that share common interests and the goal to further advance knowledge in areas such as fire weather, fuel models, and fire behaviour. 


\section{Fire management and future FDRS development in Southeast Asia}

By providing early warning of time periods when serious burning conditions will occur, forest and land management agencies are better able to implement fire management plans before fire problems begin. This includes activities in fire prevention, early detection of fires, and mobilization and preparedness of fire suppression resources. Mobilization plans for Kalimantan, Riau, and South Sumatra provinces (Anonymous 1999, 2001) are examples of existing procedures that can be integrated with FDRS through early warning. There is also great potential to develop additional plans and procedures through FDRS-based decision aids. Daily fire detection scheduling, adjustment of fire crew and equipment levels and positioning, and prevention communication are common examples of fire management activities implemented using FDRS-based decision aids (Lanoville and Mawdsley 1989; de Groot 1989a; Hirsch 1991). Because fire is usually human-caused in Southeast Asia, there is great potential to reduce fire problems through fire prevention. For example, decision aids based on ignition potential could be developed to implement a road closure strategy to restrict access to high fire danger areas, or to implement partial or full burning restrictions in specific critical areas or during certain time periods. Public communication is a key component of fire prevention, and it lends itself well to an application based on fire danger levels. Various agencies in the region are currently developing these fire management tools.

In terms of early warning, the FDRS has even greater potential when used in a forecasting mode. The FDRS is designed to provide early warning through the various levels of fire danger calculated using the current fire weather conditions so managers are forewarned before extreme burning conditions are reached. Using forecasted weather, the FDRS will provide additional capacity to determine future trends in fire danger. The amount of time that the FDRS is able to predict fire danger into the future is limited only by the availability of reliable forecasted weather data.

Further development of fuel-specific fire danger (or fire behaviour) models for Southeast Asia is anticipated. Logged forests and cutovers are examples of fuel types with increasing fire risk that require specific models to assess fire danger. A number of Southeast Asian universities participated in this project (Bogor Agricultural University, West Java; Tanjungpura University, Pontianak, West Kalimantan; Universiti Putra Malaysia, Selangor; University of Riau, Pekanbaru), and fire scientists in those institutions will play an important role in future FDRS development and applications. In particular, studies on ignition potential and fire intensity of different fuel types, further refinement of fuel type classification, and analysis of spatial fire, fuels, and FWI System data will be important for future FDRS development in the region.

The experience of developing the FDRS for Indonesia and Malaysia provided insight that can benefit the implementation of similar projects in other countries, including other nations within Southeast Asia. The most critical aspect of developing new FDRS is identification and analysis of the local fire problem. Understanding of local fire climate, vegetation as fuel, fire regime, fire management capabilities and policy, and culture is required to understand the fire problem. The next important step is to determine what information the FDRS needs to provide so that fire managers can address the fire problem. By developing the FDRS around fire management, the FDRS are designed to serve as a decision-making tool with practical application. The final step is to link the information required by fire managers to the underlying physical aspects of the fire environment that are causing the fire problem, and then connecting those factors to FDRS indicators. To illustrate the process in this project, haze was identified as the main fire problem in Southeast Asia. The underlying cause was smouldering peat fires and the best indicator of this potential is the DC, which is a relative measure of the dryness of deep organic layers in the forest floor. Airport visibility data provided the 
means to calibrate the DC to a scale that fire managers could use to make timely decisions on prevention, detection and suppression. The same process was used to assist managers in preparing for a large number of fire starts using the FFMC, hot spot data, and grass moisture and ignition studies.

There is also an institutional aspect to developing operational FDRS in another country. For the systems to be sustainable, they need to be incorporated within the regular procedures of a local agency that is experienced in daily operational systems. Meteorological agencies and some fire management agencies typically have this experience. Weather data are obviously required to operate FDRS, which can be obtained from either a meteorological service or a network of field stations operated by some forestry agencies. Spatial vegetation data is used to assess fuels, and this identification may involve a number of other agencies in the operation of FDRS, although not on a daily basis. Daily information transfer of weather data and FDRS outputs are integral to operations, so the design of a communications network between and within participating agencies is crucial.

Sustainability of new FDRS also requires local capacity strengthening. Technology transfer through workshops, training courses, and information sessions is important to the successful implementation of FDRS (Kiil et al. 1986; de Groot 1989b). Fire science education is also important to understanding FDRS principles, and this aspect can be achieved through partnerships with universities. By training people in the science and technology of FDRS, local expertise is developed in system calibration and the FDRS can be designed for other applications in the future as new fire issues and fire management practices evolve.

As previously described, increased resources are being applied to the fire and haze problem in Southeast Asia. Across the region, institutions have been expanded or newly developed, equipment and human resources for monitoring and fire control have been acquired and trained, and increased funds are being allocated for fire management activities. To ensure that the additional resources are used effectively and economically, they must be supported by more objective decision-making tools such as the FDRS.

Acknowledgements The authors gratefully recognize the significant contributions of Guswanto (Indonesian Meteorological and Geophysical Agency, Jakarta), Caren Dymond, and Irma Irawati to the Southeast Asia Fire Danger Rating System Project. We also recognize the valuable participation in the project by Wardati (University of Riau, Pekanbaru, Indonesia); John Doornbos, Sandra Williams, Steve Price, Bryan Lee, Yonghe Wang, and Marty Alexander (Canadian Forest Service, Edmonton); Adelina Kamal (ASEAN Secretariat, Jakarta); Terry Van Nest (Alberta Sustainable Resource Development); and Judi Beck and Phil Taudin-Chabot (British Columbia Forest Service). Anja Hoffmann provided helpful comments. The Southeast Asia Fire Danger Rating System Project was funded by the Canadian International Development Agency and implemented by the Canadian Forest Service.

\section{References}

Alexander ME (1989) Fiji adopts Canadian system of fire danger rating. Int For Fire News II(1):3

Alexander ME, de Groot WJ (1988) Fire behavior in jack pine stands as related to the Canadian Forest Fire Weather Index (FWI) System. Can For Serv Edmonton, AB, poster w / text

Anderson KR, Englefield P (2001) Quantile characteristics of forest fires in Saskatchewan. Proceedings of the Fourth Symposium on Fire and Forest Meteorology, Reno, NV, American Meteorological Society, Boston, pp MA, 9-16

Anonymous (1999) Pilot Project: Planning for Fire Suppression Mobilization in Riau and South Sumatra Provinces, ASEAN RETA, Jakarta, 5778 Reg (unpubl.) 103p

Anonymous (2001) Report on: Immediate Action Plan in West Kalimantan Province, Prevention and Monitoring Components, ASEAN Secretariat, Jakarta, (unpubl.) $24 \mathrm{p}$

Amiro BD, Todd JB, Wotton BM, Logan KA, Flannigan MD, Stocks BJ, Mason JA, Martell DL, Hirsch KG (2001) Direct carbon emissions from Canadian forest fires, 1959-1999 Can J For Res 31:512-525 
Applegate G, Chokkalingam U, Suyanto (2001) Underlying causes and impact of fires in Southeast Asia, Centre for International Forest Research, Bogor. Final Report (unpubl)

Brenner J, Arvanitis LG, Brackett DP, Lee BS, Carr RJ, Suddaby RM (1997) Integrating GIS, mesoscale fire weather prediction, smoke plume dispersion modeling, and the internet for enhanced open burning authorizations and wildfire response in Florida. Proceedings of the GIS User's Conference, http://aris.sfrc.ufl.edu/Laboratories/GIS/presentations/612p.htm

Buongiorno A, Arino O, Zehner C, Colagrande P, Goryl P (1997) ERS-2 monitors exceptional fire event in South-East Asia. Earth Observation Quarterly 56:1-5

Byram G (1959) Combustion of forest fuels. In: Davis KP (ed.), Forest fire: control and use McGraw-Hill, New York, pp 61-89

Cochrane MA (2003) Fire science for rainforests. Nature 421:913-919

Deeming JE, Burgan RE, Cohen JD (1977) The National Fire Danger Rating System—1978, USDA For. Serv, Intermt For Range Exp. Stn, Ogden, Utah, Gen. Tech Rep INT-39

de Groot WJ (1988) Interpreting the Canadian Forest Fire Weather Index (FWI) System. In: Hirsch KG (ed.), Proceedings of the Fourth Central Region Fire Weather Committee Scientific and Technical Seminar. Can For Serv, Edmonton, Alberta, Study NOR-36-03-1, File Rep 3, pp 3-14

de Groot WJ (1989a) Development of Saskatchewan's Fire Suppression Preparedness System. In: Hirsch KG (ed.), Proceedings of the Sixth Central Region Fire Weather Committee Scientific and Technical Seminar, Can For Serv, Edmonton, Alberta, Study NOR-36-03-1, File Rep 5, pp 23-49

de Groot WJ (1989b) Technology transfer in Saskatchewan: operational use of the Canadian Forest Fire Danger Rating System. In: MacIver DC, Auld H (eds.) Proceedings of the 10th Conference on Fire and Forest Meteorology, Atmos Environ Serv, Downsview, Ontario, pp 327-332

de Groot WJ, Bothwell PM, Carlsson DH, Logan KA (2003) Simulating the effects of future fire regimes on western Canadian boreal forests. J Veg Sci 14:355-364

de Groot WJ, Field RD (2004) Southeast Asia Fire Danger Rating System Manual. Report to the Canadian International Development Agency. Canadian Forest Service, Edmonton, Alberta Unpubl File Report

de Groot WJ Wardati, Wang Y (2005) Calibrating the Fine Fuel Moisture Code for grass ignition potential in Sumatra, Indonesia. Int J Wildland Fire 14:161-168

Dymond CC, Roswintiarti O, Brady MA (2004) Characterizing and mapping fuels for Malaysia and western Indonesia. Int J Wildland Fire 13:323-334

Dymond CC, Field RD, Roswintiarti O, Guswanto (2005) Using satellite fire detection to calibrate components of the Fire Weather Index System in Malaysia and Indonesia. Environ Manage 35:426-440

Field RD, Wang Y, Roswintiarti O, Guswanto (2004) A drought-based predictor of recent haze events in western Indonesia. Atmos Environ 38:1869-1878

Forestry Canada Fire Danger Group (1992) Development and structure of the Canadian forest fire behavior prediction system. Ottawa, ON, For Can, Rep ST-X-3

Glover D, Jessup T (1999) Indonesia's fires and haze: the costs of a catastrophe, Singapore, Singapore Institute of Southeast Asian Studies. pp 149

Heil A, Goldammer JG (2001) Smoke-haze pollution: a review of the 1997 episode in Southeast Asia. Reg Environ Change 2:24-37

Hirsch KG (1991) Development of an initial attack preparedness system for Manitoba. In: Andrews PL, Potts DF (eds.) Proceedings of the 11th Conference on Fire and Forest Meteorology, Bethesda, MD, Society of American Foresters, SAF Publ 91-04, pp 81-89

Hirsch KG (1998) Using expert judgment to model initial attack fire crew effectiveness. For Sci 44:539-549

Kiil AD, Quintilio D, Alexander ME (1986) Adaptation of a national system of fire danger rating in Alberta, Canada: a case study in technology transfer. Proceedings of the 18th IUFRO World Congress, Division 6: General Subjects, Vienna, Austria, International Union of Forest Research Organizations, pp 410 421

Kita K, Fujiwara M, Kawakami S (2000) Total ozone increase associated with forest fires over the Indonesian region and its relation to the El Niño-Southern Oscillation. Atmos Environ 34:2681-2690

Kunii O, Kanagawa S, Yajima I, Hisamatsu Y, Yamamura S, Amagai T, Ismail ITS (2002) The 1997 haze disaster in Indonesia: its air quality and health effects. Arch Environ Health 57:16-22

Lanoville RA, Mawdsley WM (1989) Systematic assessment of daily fire preparedness requirements. In: Alexander ME, Bisgrove GF (tech coord), The Art and Science of Fire Management - Proceedings of the First Interior West Fire Council Annual Meeting and Workshop, Edmonton, Alberta, Can For Serv, Inf Rep NOR-X-309, pp 253-261

Lawson BD, Armitage OB, Dalrymple GN (1994) Ignition probabilities for simulated people-caused fires in British Columbia's lodgepole pine and white spruce-subalpine fir forests. Proceedings of the 12th International Conference on Fire and Forest Meteorology, Bethesda, MD, Society of American Foresters, SAF Publ 94-02, pp 493-505 
Lawson BD, Dalrymple GN (1996) Ground-truthing the Drought Code: field verification of overwinter recharge of forest floor moisture, Victoria, BC, Can For Serv, FRDA Rep 268

Lawson BD, Frandsen WH, Hawkes BC, Dalrymple GN (1997) Probability of sustained smoldering ignition for some boreal forest duff types. Edmonton, Alberta, Can For Serv, For Manage Note 63 pp 11

Lee BS, Alexander ME, Hawkes BC, Lynham TJ, Stocks BJ, Englefield P (2002) Information systems in support of wildland fire management decision making in Canada. Computers and Electronics in Agriculture 37:185-198

Levine JS (1999) The 1997 fires in Kalimantan and Sumatra, Indonesia: Gaseous and particulate emissions. Geophys Res Lett 26:815-818

Luke RH, McArthur AG (1978) Bushfires in Australia, Canberra, CSIRO Div. For Res, Australian Gov Publ Serv

Martell DL, Otukal S, Stocks BJ (1987) A logistic model for predicting daily people-caused forest fire occurrence in Ontario. Can J For Res 17:394-401

McAlpine RS (1991) Seasonal trends in the Drought Code component of the Canadian Forest Fire Weather Index System, Petawawa, ON, For Can, Inf Rep PI-X-97

Merrill DF, Alexander ME (1987) Glossary of Forest Fire Management Terms, Fourth Edition, Ottawa, ON, Natl Res Counc Can, NRCC No. 26516

National Rural Fire Authority (1993) Fire Weather Index Tables for New Zealand, Wellington, National Rural Fire Authority

Page SE, Siegert F, Rieley JO, Beohm HDV, Jaya A, Limin S (2002) The amount of carbon released from peat and forest fires in Indonesia during 1997. Nature 420:61-65

Paul PM (1969) Field Practices in Forest Fire Danger Rating, Ottawa, ON, Can For Serv, Inf Rep FF-X-20

Pickford S, Suharti M, Wibowo A (1992) A note on fuelbeds and fire behavior in alang-alang (Imperata cylindrica). Int J Wildland Fire 2:41-46

Qadri ST (ed.) (2001) Fire, Smoke, and Haze: The ASEAN Response Strategy. Manila, Asian Development Bank and Association of Southeast Asia Nations

Quintilio D, Van Nest TA, Murphy PJ, Woodard PM (1990) Determining production rates of initial attack crews. In: Alexander ME, Bisgrove GF (tech coord), The Art and Science of Fire Management - Proceedings of the First Interior West Fire Council Annual Meeting and Workshop, Edmonton, AB, Can For Serv, Inf Rep NOR-X-309, pp 105-113

Russell RN, Pech G (1968) Development of Burning Index Tables for White Spruce-Alpine Fir and Lodgepole Pine Forest Covertypes in the Prince George Forest District (An Establishment and Progress Report), Victoria, BC, Dep Forestry and Rural Development, Forestry Branch, Int Rep BC-8

San-Miguel-Ayanz J, Barbosa P, Liberta G, Schmuck G, Schulte E, Bucella P (2003) The European Forest Fire Information System: a European Strategy Towards Forest Fire Management. Proceedings of the 3rd International Wildland Fire Conference, Sydney, Australia. Washington, D C, U S Dep Interior, Bur Land Management CD-ROM

Sastry N (2002) Forest fires, air pollution, and mortality in Southeast Asia. Demography 39:1-23

Siegert F, Ruecker G, Hinrichs A, Hoffmann AA (2001) Increased damage from fires in logged forests during droughts caused by El Niño. Nature 414:437-440

Stocks BJ, Fosberg MA, Lynham TJ, Mearns L, Wotton BM, Yang Q, Jin J-Z, Lawrence K, Hartley GR, Mason JA, McKenney DW (1998) Climate change and forest fire potential in Russian and Canadian boreal forests. Clim Change 38:1-13

Stocks BJ, Lawson BD, Alexander ME, Van Wagner CE, McAlpine RS, Lynham TJ, Dube DE (1989) Canadian Forest Fire Danger Rating System: an overview. For Chron 65:258-265

Stolle F, Lambin EF (2003) Interprovincial and interannual differences in the causes of land-use fires in Sumatra, Indonesia. Environ Conservation 30(4):375-387

Stott PA, Goldammer JG, Werner WL (1990) The role of fire in the tropical lowland deciduous forests of Asia. In: Goldammer JG (ed), Fire in the Tropical Biota: Ecosystem Processes and Challenges, New York, Springer-Verlag, pp 32-44

Taylor SW, Armitage OB (1993) Prescribed Fire Emissions Predictor - Version 1.00. User guide, Documentation and Evaluation, Victoria, BC, For Can, File Rep (unpubl.)

Turner JA, Lawson BD (1978) Weather in the Canadian Forest Fire Danger Rating System: a User Guide to National Standards and Practices, Can For Serv, Inf Rep BC-X-177

Van Wagner CE (1987) Development and Structure of the Canadian Forest Fire Weather Index System, Ottawa, ON, Can For Serv, Tech Rep 35

Van Wagner CE, Pickett TL (1985) Equations and FORTRAN Program for the Canadian Forest Fire Weather Index System, Ottawa, ON, Can For Serv Tech Rep 33

Wang Y, Field RD, Roswintiarti O (2004) Trends in atmospheric haze induced by peat fires in Sumatra Island, Indonesia and El Niño phenomenon from 1973 to 2003. Geophys Res Lett 31:L04103 doi: 10.1029/2003GL018853 